\title{
The Effects of Offshore Wind Farms on Hydrodynamics and Implications for Fishes
}

By Joshua van Berkel,

Hans Burchard,

Asbjørn Christensen,

Lars O. Mortensen,

Ole Svenstrup Petersen,

and Frank Thomsen
ABSTRACT. We review the state of knowledge about offshore wind farm (OWF) development-related effects on hydrodynamics and their possible secondary effects on fishes derived from European studies. Theoretical, modeling, and observational studies of OWF developments are relatively advanced and identify potential impacts resulting from OWF changes to local or regional hydrodynamics through modification of (1) the wind fields, and (2) oceanographic parameters including turbulence, mixing, and vertical stratification. While limited, studies discuss local OWF (i.e., within the OWF footprint) impacts on fishes due to sediment resuspension or sedimentation, temperature change, nutrient transport, and substrate availability. These studies largely neglect possible effects further afield and generally conclude that any hydrodynamic impact of OWFs on fishes cannot be distinguished when compared to natural variability. To further understanding of the cumulative risk from extensive OWF developments requires additional research on OWF-related spillover effects on surrounding ecosystems and on natural oceanographic connectivity. The use of dynamic habitat or agentbased models coupled with refined hydrodynamic models can help quantify the scale of spatial and temporal effects of hydrodynamic cues on the movement of fishes and their habitats, which is not currently possible via conventional modeling, quantitative analysis approaches, or field-based observational studies and surveys.

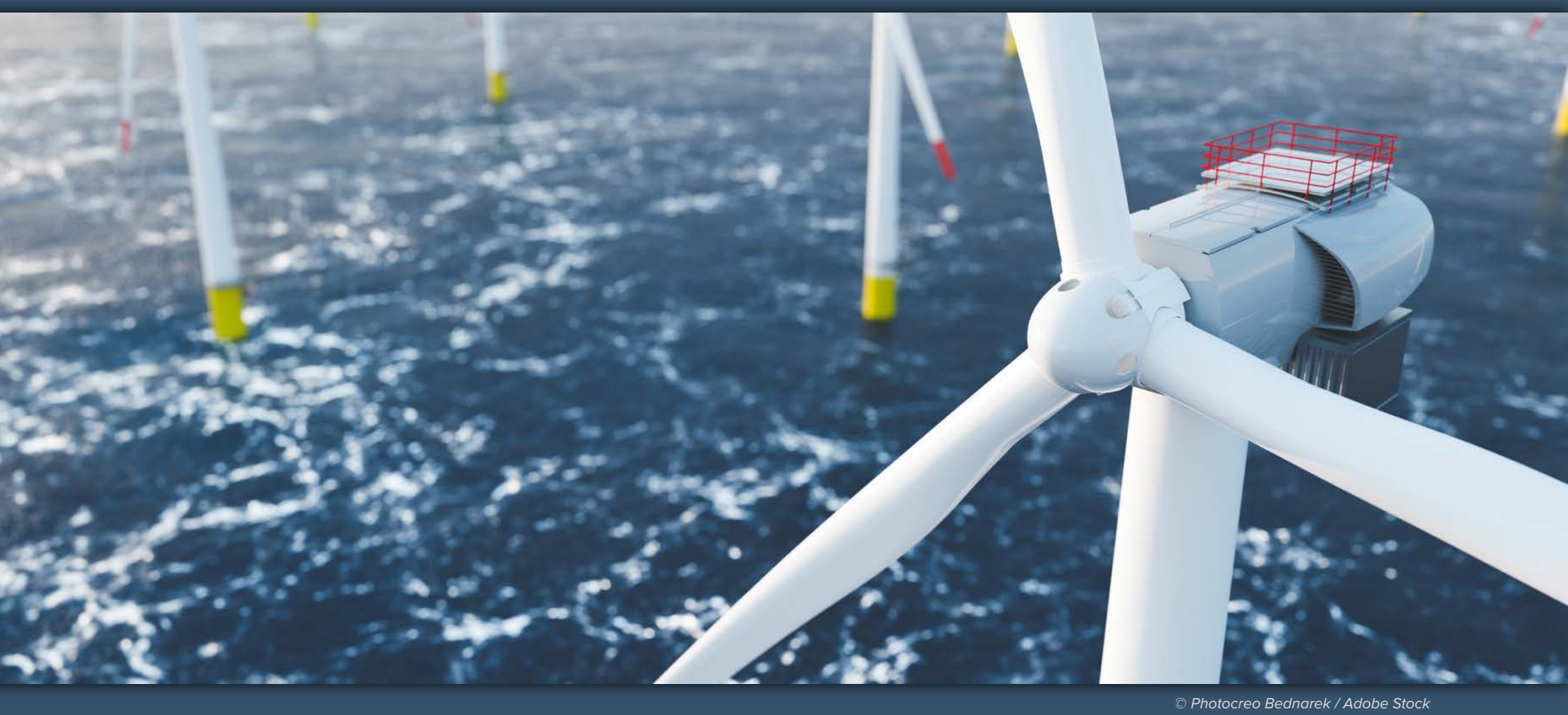




\section{INTRODUCTION}

Since the beginning of the twenty-first century, European countries have been leaders in large-scale installation of offshore wind farms (OWFs), and there are ambitious plans to further expand the industry in Europe and beyond (see map at http://www.4coffshore.com/ offshorewind). Given the scale of ongoing and planned OWFs and marine renewable energy developments in general-wind, wave, and tidal power devices-the environmental impacts of such installations on ecosystem components require increasing attention (Boehlert and Gill, 2010).

The construction, operation, and decommissioning phases of offshore wind farms all exert pressures on marine environmental receptors (i.e., plankton, benthos, fish, turtles, birds, marine mammals, and bats; see reviews by Gill, 2005; Boehlert and Gill, 2010; Thomsen et al., 2015). In this regard, the attraction of benthos and fishes to newly introduced hard substrates, called the artificial reef effect (see Mineur et al., 2012; Degraer et al., 2020, in this issue; Glarou et al., 2020), has been a focus of impact analysis, but offshore wind development effects on hydrodynamics and their possible secondary effects on fishes have received less attention. Plans to expand OWF development and the evident role hydrodynamics plays in the life cycles of fishes suggest that a systematic review of the current state of knowledge regarding these potential impacts is warranted.

The role and importance of hydrodynamics in the life cycles of fish species becomes evident when examining their habitats. Fishes can occupy single or multiple habitats during their life cycles, but the most common habitual contexts are spawning, nursery, settlement, feeding, refugia, and migration/transport routes. The two main spawning habitats are demersal and pelagic. The spawning habitat preference of demersal spawners is species specific, and eggs are typically laid on the sedimented seafloor, algae, or boulders. Pelagic spawners produce free-floating eggs that are fertilized in the water column, often in large, lesswell-defined spawning grounds that may vary from year to year. Because pelagic spawning takes place mostly at depths of 20-100 m, hydrodynamic and hydrographic conditions play an important role in regulating spawning ground boundaries. Hydrodynamics also influences refugia and migration/transportation routes, as the eggs and/or larvae of both pelagic and demersal spawners passively or actively drift with ocean currents. A variety of environmental factors such as currents, wind, turbidity, temperature, and planktonic abundance regulate the transport and development of eggs and larvae. Coastal areas provide habitats for a variety of different species-dependent vital processes, for example, nursery, settlement, feeding, and refugia. Hydrodynamics play a pivotal role in controlling turbidity, sedimentation, salinity, temperature, and nutrient uptake in coastal systems, conditions known to influence survival success, even though precise biological mechanisms often remain elusive.

Here, we review the effects of OWFs on hydrodynamics and the associated implications for fishes. We characterize the hydrodynamic conditions of typical European OWF locations and provide a synopsis of the results of studies concerning the hydrodynamic effects of OWFs on fishes and their habitats. We conclude our review with a summary of the state of knowledge and by offering potential areas for further research.

\section{HYDRODYNAMIC CHARACTERISTICS OF EUROPEAN OFFSHORE WIND FARM SITES}

According to Wind Europe (https:// windeurope.org/), the European countries that have extensive OWFs are (in decreasing amounts of installed megawatts) the United Kingdom, Germany, Denmark, Belgium, and the Netherlands. The coastal regimes in which the OWFs are installed exhibit a wide range of ecosystem types and are highly diverse in hydrodynamic characteristics as a function of water depth, tides, currents, waves, meteorological forcing, and stratification. Most of the OWFs are installed in the North Sea, mainly in the southeastern part of the German Bight and along the southeastern English coast. Additional OWFs are located in the Southern Bight of the North Sea near the west coast of Belgium and the Netherlands, offshore from the mouth of the Thames, in the English Channel, in the Irish Sea near the English and Welsh coasts, in the Skagerrak between Norway and Denmark, and in the western Baltic Sea. OWFs installed outside these regions are relatively small. These European OWF focus areas can be hydrodynamically divided into five regimes summarized in Table 1. Figure 1 delineates areas where these regimes occur.

\section{IMPACTS OF OFFSHORE WIND FARMS ON COASTAL HYDRODYNAMICS}

OWFs may directly impact the hydrodynamics inside of and near the OWF and close by through their underwater infrastructure, or indirectly by changing the wind field. These local alterations result in a modified ocean response to surface wind stress. Methods for investigating these impacts in situ and through remote sensing, as well as via numerical model simulations, are available and are robust where appropriately applied. Both methods have their strengths and limitations such that most reliable results are obtained by optimally combining observations and scenario modeling.

\section{Effects of Underwater Structures}

Structure-induced friction and blocking are two locally generated effects of the wind turbines' underwater foundations (Sumer and Fredsøe, 1997). The prototype of such a structure-flow interaction is the homogeneous flow past a cylinder. Downstream of the foundation, under ideal conditions, a von Kármán vortex street should develop under idealized conditions, consisting of alternating eddies in the wake of the cylinder (e.g., van Dyke. 1982). By using a hydro- 
static ocean model in an idealized configuration, Grashorn and Stanev (2016) reproduced the von Kármán vortex streets behind cylinders in steady flow. Because these vortex streets are expected to be largely nonhydrostatic, it can be assumed that these results are quantitatively unreliable. The observed locally enhanced levels of turbulence in the wake of the cylinder found by Grashorn and Stanev (2016) and the resulting increased sediment erosion and turbidity in the water column therefore require further investigation by means of Large Eddy Simulations (LES).

A more significant environmental issue potentially caused by OWFs is the alteration of the seawater's vertical den- sity stratification (Rennau et al., 2012; Floeter et al., 2017). Although it has been long neglected in fluid dynamics, stratified flow past fixed structures needs to be considered when constructing OWFs. In a first large-scale, in situ experiment, Lass et al. (2008) collected observations of flow properties in stratified waters downstream of the western part of the Great Belt Bridge in Denmark. They found strong vertical mixing and internal wave generation close to the bridge pylons. Typical bottom-to-surface salinity differences for these salinity-dominated weakly tidal regimes are about $5-10 \mathrm{~g} \mathrm{~kg}^{-1}$ (corresponding to a density difference of about $3.5-7 \mathrm{~kg} \mathrm{~m}^{-3}$ ) at depths of $20-40 \mathrm{~m}$, a value that strongly varies in time and space.

Rennau et al. (2012) derived parameterizations for structure-induced mixing to use in ocean models of nontidal density-driven flow, which has different mixing properties than tidal flow, by conducting LES analysis of stratified flow past $10 \mathrm{~m}$ diameter cylinders and calculating the structure-induced vertical buoyancy flux. To permit a range of structureinduced mixing efficiencies by shapes other than circular cylinders, Rennau et al. (2012) considered cases of weak mixing and strong mixing, where the latter was considered an upper limit. For seasonally stratified tidal flow, Carpenter et al. (2016) followed a similar approach

TABLE 1. Description of five dynamic offshore wind farm regimes in the North Sea and the Irish Sea.

\begin{tabular}{|c|c|c|c|c|c|}
\hline 필 & $\begin{array}{c}\text { Seasonally } \\
\text { stratified shelf seas }\end{array}$ & $\begin{array}{c}\text { Intermittently } \\
\text { stratified tidal areas }\end{array}$ & $\begin{array}{l}\text { Well-mixed shallow } \\
\text { tidally dominated } \\
\text { coastal sites }\end{array}$ & $\begin{array}{c}\text { Tidal regions of } \\
\text { freshwater influence } \\
\text { (ROFIs) }\end{array}$ & $\begin{array}{c}\text { Permanently } \\
\text { stratified weakly tidal } \\
\text { shelf seas }\end{array}$ \\
\hline$\frac{8}{2}$ & $\begin{array}{l}\text { - Two-layer thermal } \\
\text { stratification in summer, } \\
\text { fully mixed in winter } \\
\text { - Water depths of } \\
\text { >40-100 m, strongly } \\
\text { depending on local } \\
\text { conditions } \\
\text { - Stratifying agent: } \\
\text { summer surface } \\
\text { warming } \\
\text { - De-stratifying agent: } \\
\text { autumn cooling, tidal } \\
\text { energy, and wind stress } \\
\text { (Burchard et al., 2002) } \\
\text { - Thermocline in summer } \\
\text { inhibits vertical } \\
\text { exchange between } \\
\text { bottom and surface } \\
\text { layers. After spring } \\
\text { bloom, surface waters } \\
\text { are nutrient-depleted } \\
\text { and bottom waters are } \\
\text { nutrient-rich. }\end{array}$ & $\begin{array}{l}\text { - Water depths } \\
\text { - <40 m depth, strongly } \\
\text { depending on local } \\
\text { conditions } \\
\text { - Located near tidal fronts } \\
\text { between seasonally } \\
\text { stratified and well- } \\
\text { mixed regions (Simpson } \\
\text { and Hunter, 1974) } \\
\text { - Tidal fronts move with } \\
\text { the spring-neap cycle, } \\
\text { the wind forcing and } \\
\text { the seasonal cycle of } \\
\text { heating and cooling } \\
\text { - Tidal fronts are hotspots } \\
\text { for primary production } \\
\text { (Tett, 1981) }\end{array}$ & $\begin{array}{l}\text { - Depths <20 m, away } \\
\text { from influences of river } \\
\text { runoff } \\
\text { - Comparably simple } \\
\text { hydrodynamics } \\
\text { - Wave influences } \\
\text { significant when long } \\
\text { wind waves impact the } \\
\text { bottom (Mellor, 2002) }\end{array}$ & $\begin{array}{l}\text { - Situated downstream } \\
\text { of large freshwater } \\
\text { discharges from rivers } \\
\text { - Horizontal density } \\
\text { gradients generated by } \\
\text { the river runoff induce } \\
\text { periodic stratification } \\
\text { that interacts with the } \\
\text { tides (Simpson et al., } \\
\text { 1990) } \\
\text { - Strong implications } \\
\text { for vertical mixing and } \\
\text { residual transports }\end{array}$ & $\begin{array}{l}\text { - Occurs in waters } \\
\text { between North Sea } \\
\text { and Baltic Sea } \\
\text { - Horizontal salinity } \\
\text { gradient drives residual } \\
\text { exchange flow } \\
\text { - North Sea water enters } \\
\text { the Baltic Sea near the } \\
\text { bottom and brackish } \\
\text { surface water leaves } \\
\text { the Baltic Sea (Burchard } \\
\text { et al., 2018) } \\
\text { - Strong modifications } \\
\text { by episodic Major } \\
\text { Baltic Inflows (MBls) } \\
\text { occurring on average } \\
\text { at decadal timescales } \\
\text { (Mohrholz, 2018) } \\
\text { - MBls ventilate anoxic } \\
\text { basins of the Central } \\
\text { Baltic Sea (Reissmann } \\
\text { et al., 2009) }\end{array}$ \\
\hline$\frac{4}{2}$ & $\begin{array}{l}\text { Europe: } \\
\text { - Central North Sea } \\
\text { - Central Irish Sea } \\
\text { - Celtic Sea }\end{array}$ & $\begin{array}{l}\text { - Southern North Sea } \\
\text { (Dogger Bank, Oyster } \\
\text { Ground, Outer German } \\
\text { Bight regions) } \\
\text { - Irish Sea (intermediate } \\
\text { depths) }\end{array}$ & $\begin{array}{l}\text { - Shallow coastal regions } \\
\text { of North Sea, Irish } \\
\text { Sea, English Channel, } \\
\text { Celtic Sea }\end{array}$ & $\begin{array}{l}\text { - Liverpool Bay } \\
\text { (Simpson et al., 2002) } \\
\text { - Rhine (Simpson and } \\
\text { Souza, 1995) } \\
\text { - Elbe-Weser } \\
\text { (Chegini et al., 2020) }\end{array}$ & $\begin{array}{l}\text { - Baltic Sea } \\
\text { - Kattegat }\end{array}$ \\
\hline$\frac{11}{2}$ & $\begin{array}{l}\text { - Sørlige Nordsjø } \\
\text { (Norway) }\end{array}$ & $\begin{array}{l}\text { - Hornsea Project One } \\
\text { (United Kingdom) } \\
\text { - Arklow Bank Phase } 2 \\
\text { (Ireland) }\end{array}$ & $\begin{array}{l}\text { - Robin Rigg } \\
\text { (United Kingdom) } \\
\text { - Horns Rev (Reef) } 3 \\
\text { (Denmark) }\end{array}$ & $\begin{array}{l}\text { - Burbo Bank } \\
\text { (United Kingdom) } \\
\text { - Norther (Belgium) }\end{array}$ & $\begin{array}{l}\text { - Anholt (Denmark) } \\
\text { - Arkona (Germany) }\end{array}$ \\
\hline
\end{tabular}


of structure-induced turbulence production. For the German Bight, they calculated that the loss of tidal energy to turbulence is between $4 \%$ and $20 \%$ of the energy loss due to bottom friction. A recent study by the same group (Schultze et al., 2020) using an LES model to quantify structure-induced mixing found that about $10 \%$ of the turbulence generated by the structure is used for mixing.

In a model application to the western Baltic Sea, comparing scenarios without OWFs and with the OWFs planned in 2010 (>1,000 wind turbines), Rennau et al. (2012) concluded that strong mixing reduced the mean salinity of the bottom waters flowing from the western Baltic Sea toward the Baltic proper by $0.02 \mathrm{~g} \mathrm{~kg}^{-1}$ for a scenario with strong mixing that was due to OWFs. Also, the maximum salinity was reduced. This reduction was visible in the model results at a sill about $100 \mathrm{~km}$ further into the Baltic Sea, and it can be assumed that it would also be measurable in the central Baltic Sea (located outside the model domain). Compared to the variability with a standard deviation of about $2 \mathrm{~g} \mathrm{~kg}^{-1}$ from the mean of $14 \mathrm{~g} \mathrm{~kg}^{-1}$ observed in model results with and without OWFs, these reductions were, however, negligible. A stronger reduction in salinity by $0.42 \mathrm{~g} \mathrm{~kg}^{-1}$ of waters flowing across the sill into the Baltic Sea was found to occur only for unrealistically extensive OWFs modeled for the western Baltic Sea. With this large-scale regional effect on salinity, the ventilation of the bottom waters in the central Baltic Sea could be reduced, intensifying anoxia, if large parts of the western Baltic Sea were covered with OWFs.

For the German Bight, at a site of about $40 \mathrm{~m}$ water depth and a bottomto-top density difference of about $3 \mathrm{~kg} \mathrm{~m}^{-3}$, the order-of-magnitude estimate by Carpenter et al. (2016) found comparable results in the sense that only massively extended OWFs could cause a significant environmental effect by increasing mixing and reducing stratification. The exist- ing 160 turbines in the German Bight in 2016 would not significantly decrease stratification there. Locally (i.e., inside OWFs), stratification would be reduced by an amount dependent on the ratio of the time a water parcel remained inside an OWF and the time required for full mixing of the water column. These theoretical estimates could be partially supported by in situ observations in the German Bight carried out by Floeter et al. (2017), although admittedly, natural variability and OWF impacts could only partially be separated. However, extensive installations covering large parts of the German Bight could lead to a measurable largescale reduction in stratification, with as yet unknown environmental consequences (Carpenter et al., 2016).

Cazenave et al. (2016) applied an unstructured grid model to the Irish Sea that included the shelf seas around Britain, thereby enabling resolution of individual (cylindric) wind turbine foundations. No specific parameterization of structure-

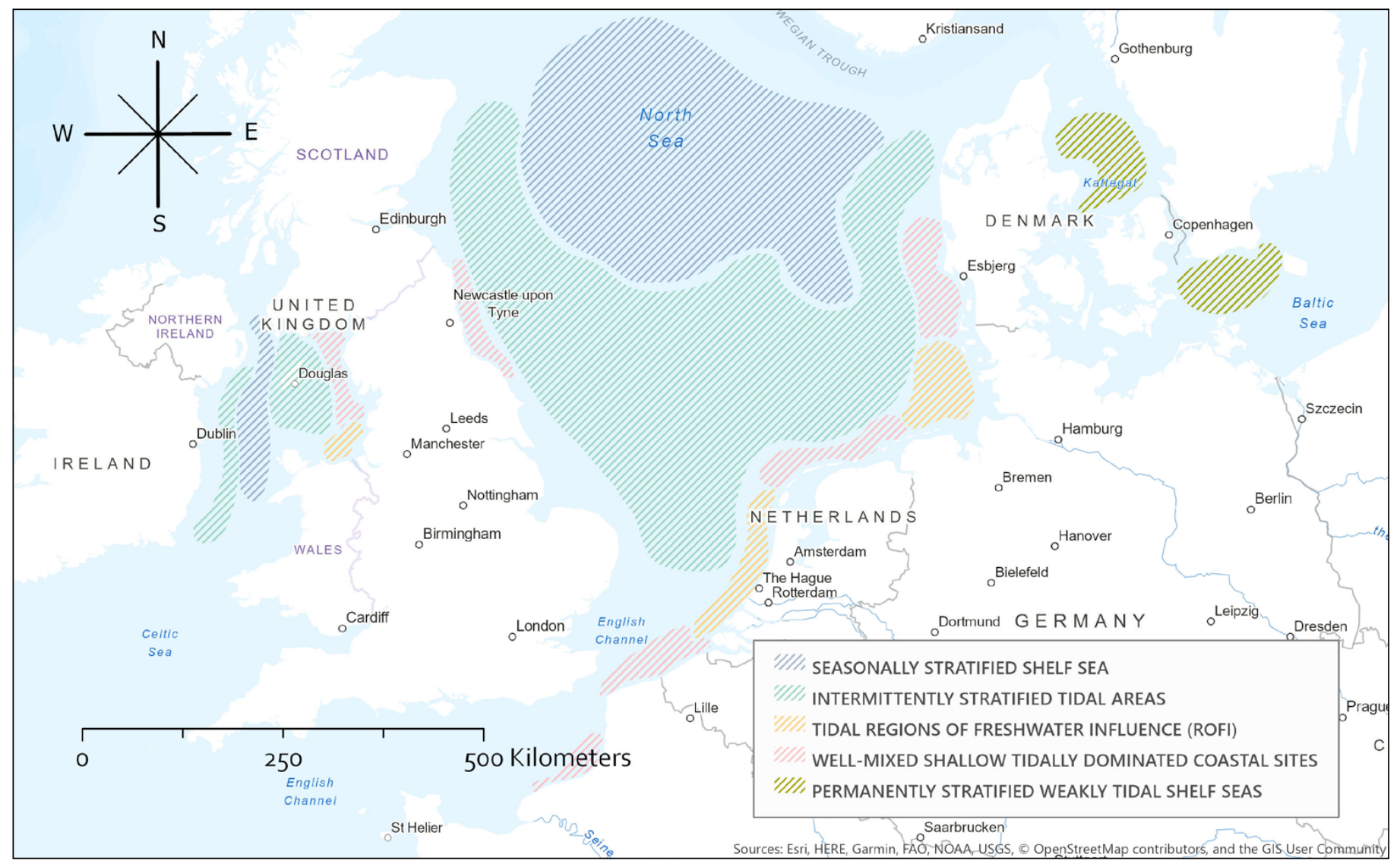

FIGURE 1. Example areas of five dynamic regimes in the North Sea and the Irish Sea. 
induced hydrodynamics and mixing was included, so the results should be interpreted with caution. Hindcast scenarios without OWFs and with 242 wind turbines installed in the eastern Irish Sea were compared. The semi-diurnal tidal range increased by an unrealistic $0.2 \mathrm{~m}$ in large parts of the Irish Sea.

In a recent study focusing on dynamic effects of OWF foundations in a stratified region of the North Sea, Schultze et al. (2020) found that wakes can be quite narrow and energetic. The wake extent depends not only on ambient stratification but also on specifying what actually belongs to the wake. Depending on the sizes of the wakes, Floeter et al. (2017) suggest there could be a joint blocking effect involving an entire OWF. Consequently, part of a water mass approaching an OWF could tend to part and flow around the OWF and rejoin after passing the area. This blocking could lead to a wake effect comparable to the island mass effect discussed by Simpson et al. (1982), with increased mixing downstream of the OWF leading to destratification and upwelling effects that impact primary production. The observations by Floeter et al. (2017) do not, however, give clear evidence of such large-sale regional effects, which are probably small (due to the relatively low OWF blocking effect) compared to natural variability and the wind wake effect (see below).

\section{Effects of Wind Turbines}

\section{on the Wind Field}

OWF wind power extraction results in reduced wind speeds locally inside the installation's footprint and regionally as a downwind wake. This process leads to wind stress curl at the edge of the wake, which is known to drive upwelling/ downwelling dipoles (adjacent regions of upward and downward vertical velocity in the water driven by friction and Earth's rotation). Such wakes can extend 5-20 km in the downwind direction, depending on weather conditions (Christiansen and Hasager, 2005).

In an idealized model study, Broström
(2008) showed that regional wind stress deficits in OWF wakes could lead to upwelling/downwelling dipoles of the order of a meter per day in vertical velocity at moderate wind speeds, if the size of the wake were comparable to the internal Rossby radius of deformation (5-20 km in the German Bight, Krause et al., 1986; and $4-7 \mathrm{~km}$ in the western Baltic Sea, Fennel et al., 1991). These results were confirmed by a modeling study conducted by Nerge and Lenhart (2010) that applied reduced wind stresses in the wake area of an OWF in the North Sea. At the extreme, Ludewig (2015) showed that the wind wake effect may result in a reduction in wind speed in a region up to 100 times larger than the OWF area itself. Applying such modified wind stress fields to a realistic model of the North Sea resulted in strong upwelling/ downwelling dipoles at the edges of the wake area, with associated vertical velocities of up to 3-4 m per day.

Van der Molen et al. (2014) simulated the effect of a hypothetical large wind farm located in well-mixed shallow waters by reducing the wind speed inside the wind farm by $10 \%$. The decline in wind speed led to locally reduced wave height and sediment erosion inside the wind farm, which decreased turbidity and increased primary production. This result disagrees with the findings by Grashorn and Stanev (2016) and Rivier et al. (2016), who reported increased turbidity caused by OWF foundations.

Lampert et al. (2020) provide airborne observations of a large-scale regional reduction in wind stress downwind of the OWF in the German Bight, confirming results of previous studies (e.g., Djath et al., 2018; Djath and Schulz-Stellenfleth, 2019; Cañadillas et al., 2020; Siedersleben et al., 2020). Consistent with the observations by Lampert et al. (2020), atmospheric model simulations by Siedersleben (2019) show a reduction of wind speed by $5 \%-25 \%$ inside the wind wake $5 \mathrm{~km}$ downwind of a wind farm. The wake effect may be highly variable and strongly depends on atmospheric conditions.

\section{IMPLICATIONS FOR FISHES}

Based on the studies noted above, it is evident that the hydrodynamic-related impacts of OWFs are relatively well studied and can be broadly categorized as being either local, within an OWF, or regional, at the periphery of an OWF and further afield, with the related impacts outlined in Box 1.

Assessing the implications of the OWF-induced hydrodynamic changes described above should ideally be possible through BACI (before-after-controlimpact) surveys (Smith, et al., 1993). The aim of the BACI method is to estimate the state of the environment before and after (BA) any change and to compare changes at reference sites (or control sites) with the actual area of impact (CI; the wind farm area). Any set of ecosystem/environmental variables can be monitored within a BACI-type survey, but investigations are usually limited to abundance and diversity metrics for fauna. If sampling is sufficiently representative, the measurements should, in principle, allow the disentanglement of OWF impacts from exterior regional trends.

A number of factors make it difficult to extract hydrodynamic impacts on fish from BACI surveys, including the spatiotemporal variability of the natural system (Bergström et al., 2013; Floeter et al., 2017), regional/global trends (e.g., accelerating climate change), and the focus of investigations on selected fish species (e.g., Wahlberg and Westerberg, 2005; Wilhelmsson et al., 2006; Reubens et al., 2011, 2013; van Deurs et al., 2012). These factors, as well as altered management that limits fishing inside OWFs (Bergström et al., 2014), make it difficult to segregate the variables behind positive and negative impacts across species. This challenge is clearly evident in terms of spatiotemporal variability alone, given the hydrodynamic variability in OWF areas described above and the documented annual variability in recruitment of juveniles, which can, for example, differ by a factor of five for plaice, 50 for sole, and more than 100 for haddock (OSPAR, 2000). Due to this nat- 
ural variability, it is evident that investigations of OWF impacts on fishes have concentrated on the local-scale impact where these contrasts are most easily resolved.

\section{Implications at the Local Scale}

When reviewing hydrodynamic implications for fishes at the local scale, stressors include changes in temperature, nutrient transport, turbulence, and stratification, and resulting impacts on sediment resuspension or sedimentation. While the effects of each hydrodynamic parameter on fish ecology are well studied in general (Liao and Cotel, 2013; Kjelland et al., 2015; Wenger et al., 2017), studies of the effects specifically related to OWFs are less comprehensive. This section focuses on documented hydrodynamic effects studied in and around OWFs.

Changed current and chlorophyll profiles close to OWFs are well documented (Maar et al., 2009), but such perturbations were not discernible at larger scales (>200 km) against a background of natural spatiotemporal variability. At the same time, changes in the demersal community were observed close $(<50 \mathrm{~m})$ to the OWF, likely in this case due to increased local fecal pellet excretions from mussels (Maar et al., 2009). Increased vertical mixing within OWFs leads to doming of the thermocline and subsequent transport of nutrients into the surface mixed layer. Floeter et al., (2017) found that nutrients were rapidly consumed by primary producers.

A study of Horns Reef in the North Sea after deployment of the wind farm there revealed changes in densities of the most commonly occurring fish, whiting (Merlangius merlangus) and dab (Limanda limanda), but the changes mostly reflected the general trend of these fish populations in the North Sea, as indicated by the International Council for the Exploration of the Sea (ICES) fish stock assessment. No significant changes in the abundance or distribution patterns of pelagic and demersal fish were found in acoustic surveys, neither between a control site and the wind farm site nor

\section{BOX1. SUMMARY OF LOCAL AND REGIONAL HYDRODYNAMIC IMPACTS}

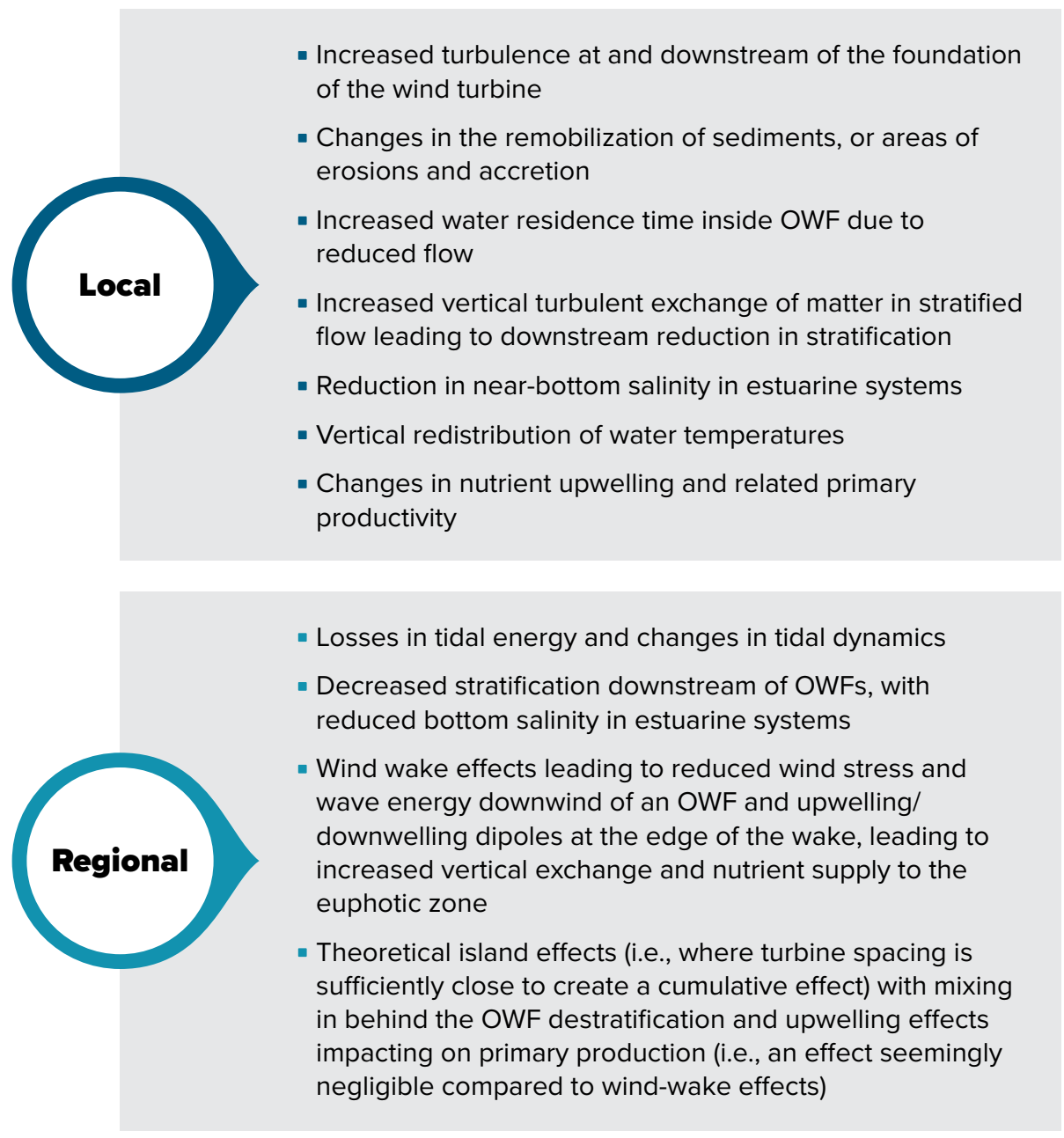

inside the impact area between foundations, due to significant temporal variation and patchiness in the distribution patterns of fish densities and biomass (Stenberg et al., 2015).

Gray and Kingsford (2003) indicated that thermocline depth is not a cue for larvae to regulate their vertical positions. Also, it is unclear how thermocline doming may affect vital rates of local larvae/fish (mortality, growth, cost of responding). For the local pelagic habitat, OWF-induced hydrodynamic changes did not appear to have a significant direct or indirect influence on pelagic fish, as inferred from hydroacoustic records that did not show any OWF effects on pelagic fish distribution (Floeter et al., 2017). However, a single cruise from another study found elevated abundances of pelagic fish, most likely mackerel, within $100 \mathrm{~m}$ of underwater construction sites (Schröder et al., 2013).

Hydrodynamic resuspension of sediments alters turbidity, thereby affecting the outcome of predator-prey encounters. Prey may evacuate the affected area to avoid predation risk while predators are attracted to areas where they experience increased ambush success. This is evident in lakes where visibility changes resulting from plankton blooms may cause trophic cascades (Scheffer et al., 2001). Laboratory and field investigations of coastal OWFs showed that pelagic species such as herring and smelt began to flee areas when the concentration of fine-grained suspended sediment reached approximately $10 \mathrm{mg}^{-1}$ and $20 \mathrm{mg} \mathrm{l}^{-1}$, respectively (COWI/VKI, 1992). In contrast, flatfish 
are generally very tolerant of high concentrations of suspended sediment. Studies of plaice with suspended sediment concentrations of $3 \mathrm{~g} \mathrm{l}^{-1}$ showed no effect after a 14-day exposure (Moore, 1991).

Increased downstream turbulence modifies predator-prey encounter rates for planktonic species. An early study by Kiørboe and MacKenzie (1995) indicated that increased turbulence levels increase fish larval encounter rates, and thus growth rates, if growth locally is encounter-limited. Simple estimates of passive larval residence time at OWF installations will likely reveal negligible effects. Late larvae with developed swimming ability may, however, feed there for extended periods. To our knowledge, this hypothesis has not been tested in situ.

\section{Implications at the Regional Scale}

Empirical demonstration of OWF impacts at the regional scale is even more challenging due to natural spatiotemporal variability of the systems (Bergström et al. 2013; Floeter et al., 2017), as well as regional/global trends driven by other factors. Consequently, this review can only report a few findings regarding the impacts of OWFs on ecosystems surrounding OWFs. One regional modeling study (Slavik et al., 2019) concluded that primary production will decline because OWFs provide new habitats to filter feeders like blue mussels. An increase in filter feeders could counteract the stirring effect that should increase primary production in stratified areas.

There has been limited study of the hypothesis that OWF development disturbs fish larvae transport pathways. This area of influence has been explored numerically in the North Sea (Figure 2), where local spawning and the destinations/origins of settling larvae were traced in the vicinity of the Horns Reef OWF. It is not clear whether the potential perturbation of marine connectivity by man-made offshore structures would exceed the natural temporal variability in dispersal patterns.

\section{RECOMMENDED FURTHER ANALYSES}

When comparing identified hydrodynamic impacts against available fish studies, it is apparent that some local OWF-related hydrodynamic-induced impacts have been explored, but not those categorized as regional. When looking specifically at knowledge gaps in this regard, three coupled area scales could be expected to be important in a specific impact assessment:

1. The accumulated physical area occupied by OWF installations

2. The accumulated area affected by hydrographic changes beyond a threshold

3. The habitat area fraction per species affected by hydrographic changes caused by OWF installations

The latter scale is expected to determine the ecosystem response, which is generally thought to be nonlinear and mediated indirectly via trophic interactions from the most affected species. Further exploration of this "spillover effect" and disturbance of natural oceanographic connectivity of certain fish species is recommended. This research would enhance the knowledge base and stakeholder perceptions of OWF-induced hydrodynamic risks and impacts on fishes.

\section{Spillover Effects on}

\section{Surrounding Ecosystem}

A key idea of marine protected areas (MPAs) is that they create a spillover effect (export) of protected species to the surrounding ecosystem. The hypothesis that OWF impacts on some species create a spillover effect on the surrounding
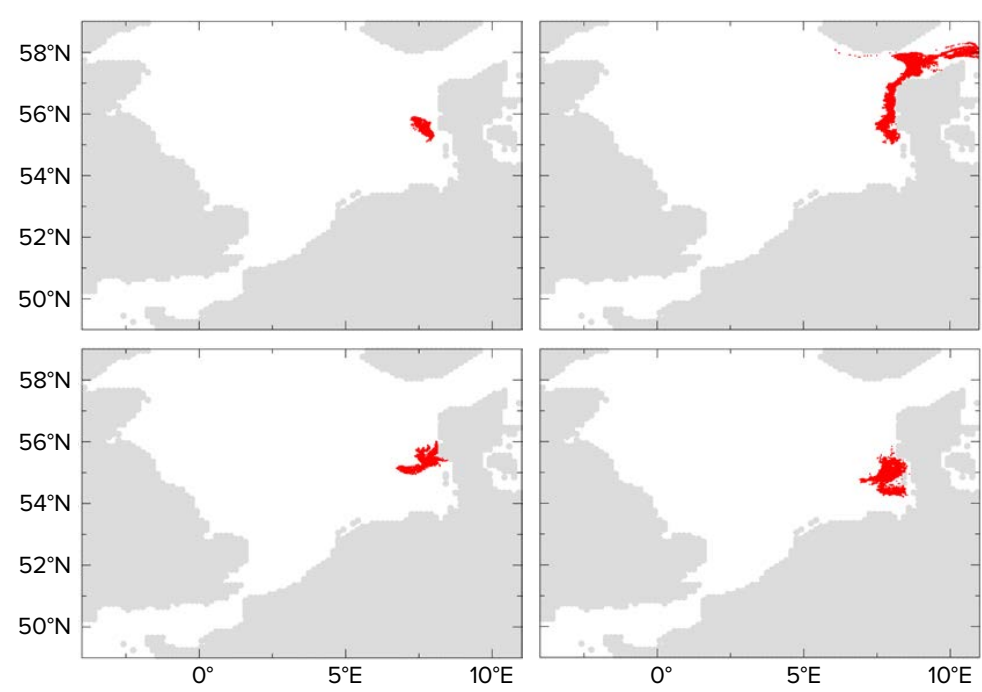

FIGURE 2. Simulation results for passive drift of 100,000 greater sand eel larvae (H. lanceolatus), illustrated via the red shaded areas. (upper left) 2005 forecast simulation of passive drift of larvae. (upper middle) 2006 forecast simulation. (lower left) 2005 backtracking simulation. (lower middle) 2006 backtracking simulation. (right) Locations of Horns Reef. From Stenberg et al. (2011)

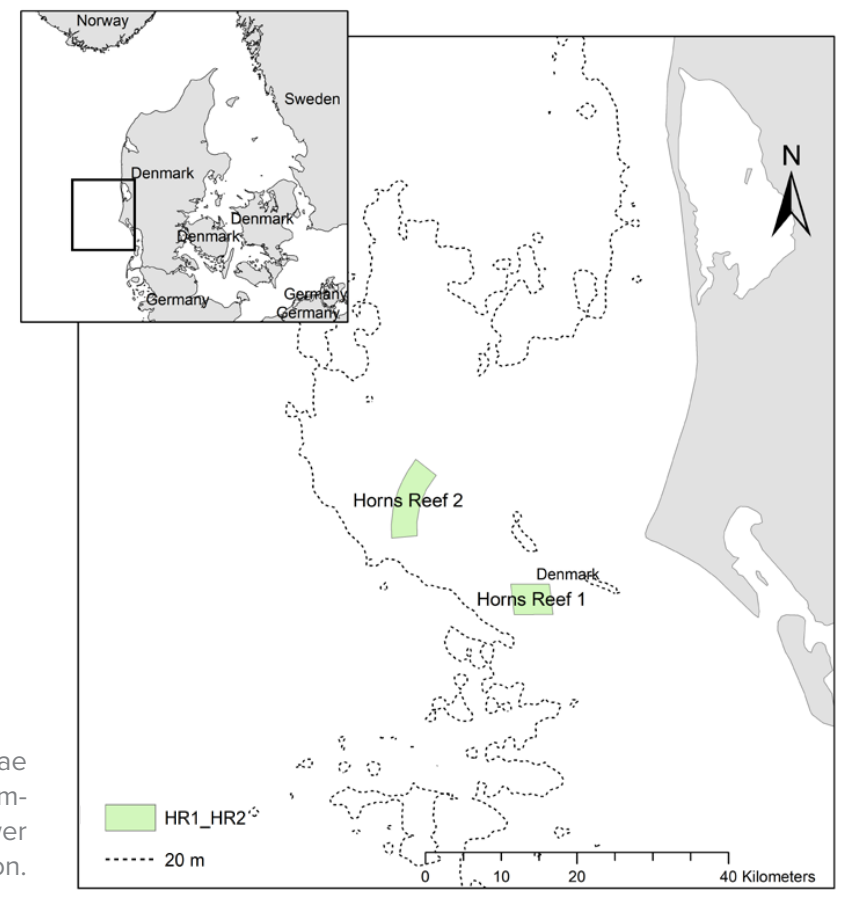


ecosystem is related to the observation that OWFs are de facto MPAs with respect to traditional fishing activity. Therefore, studies of OWF and MPA impacts on surrounding ecosystems may learn from each other. Initial attempts to quantitatively model the spillover hypothesis in relation to OWFs have been accomplished (Halouani et al., 2020), and they may, in fact, improve current MPA design guides (Halpern, 2003). Conversely, MPA studies on regional connectivity (Christensen et al., 2009), their impacts on fisheries (Pérez-Ruzafa et al., 2008), and their potential socioeconomic consequences at regional scales (Hoff et al., 2013) may provide evidence on the scale of OWFs.

\section{Further Studies Through Advanced Numerical Modeling}

Future research would benefit from, and should ultimately also entail, intensified integrated modeling that combines hydrodynamic and marine ecosystem parameters (e.g., as shown in Figure 3). In this regard, hydrodynamic models integrated with dynamic habitat and/or stochastic agent-based models (ABM) link the distribution models (dynamic habitat and agent-based) with habitat variables (oceanographic cues) produced by the high-resolution hydrodynamic model. ${ }^{1}$ With dynamic habitat modeling, generalized additive models (GAMs) enable descriptions of the assumed nonlinear relationships between the observed species and measured environmental predictors (Skov et al., 2016) to determine habitat preference. With ABM, the movements of particles, called agents, are modeled using a Lagrangian approach that permits the distinct modeling of an activity. This model is then coupled with a classic Eulerian framework that simulates the hydrodynamics of the aquatic system. The simulated agents within the model domain, which can be fish or other marine species, are capable of reacting to Eulerian gradients such as water temperatures or flow velocities (see Thomsen et al., 2019; Figure 3).

Integrated dynamic habitat and agentbased modeling approaches make it possible to investigate the potential effects of hydrodynamic cues on the movement of aquatic organisms at complex spatial scales over time. In the context of OWF hydrodynamic impacts on fishes, they would permit quantification of the benthic and pelagic habitat area affected for each species, which is not currently possible using conventional modeling approaches or simple quantitative analysis. Using either modeling approach would inform related decision-making processes regarding environmental risk and impact within a context of natural variability. Using high performance com- puting and data assimilation, these data and computationally heavy models can improve impact prediction and support real-time environmental monitoring and management applications.

\section{CONCLUSIONS}

During the last decade, a number of modeling and observational studies attempting to quantify hydrodynamic and associated ecosystem impacts of OWFs have been conducted. It can be concluded that hydrodynamic impacts are transferred to the ocean via two routes: (1) modification of the wind field and, consequently, the wave and current fields due to the direct effect of power extraction from the wind, and (2) wind turbine foundations' effects on ocean currents and consequently on turbulence, mixing, and vertical stratification. The two routes interact nonlinearly. Hydrodynamic studies of this complex problem have thus far concentrated on two aspects of these impacts, modifications of the wind field and structureinduced friction in the water column.

With regard to fishes, the data sampling density of typically applied BACI studies make it difficult to disentangle hydrodynamic impacts from natural variability. Existing peer-reviewed studies provide limited coverage of local OWF-induced (e.g., within the OWF footprint) turbulence and destratification impacts on

1 These integrated models can also be integrated with environmental stressor models, for example, underwater noise or oil spill models.
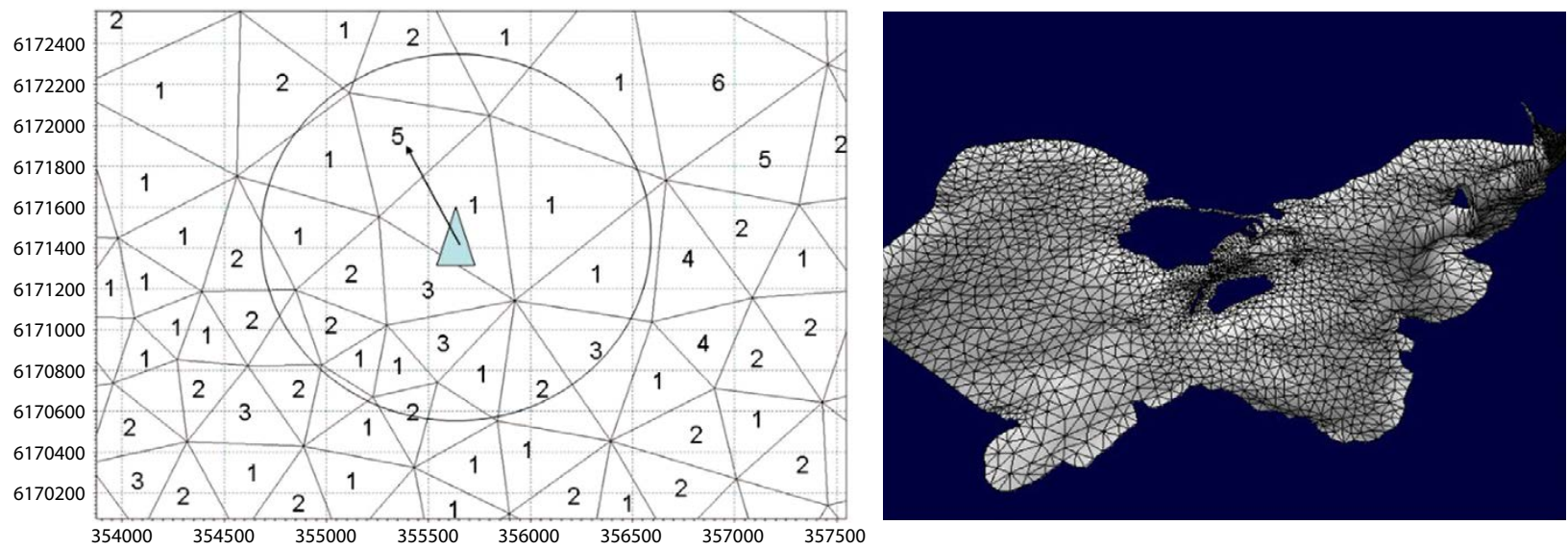

FIGURE 3. (left) Example of a generic hydrodynamic model mesh. (right) Example of an agent (blue triangle) navigating grid cells of a generic hydrodynamic model mesh. From Thomsen et al. (2019) 
fishes, for example, sediment resuspension or sedimentation, temperature, and nutrient transport. Regional impacts are largely neglected. Studies that have been undertaken tend to indicate that the ecosystem impacts are of comparable scale to natural variability given the currently existing or planned extent of OWFs.

Considering essential decision-making processes regarding environmental risk and impact, as well as suggested cumulative risks from extensive OWF development in coastal regions, we recommend further analyses of accumulated and spillover effects on surrounding ecosystems as well as disturbances to natural oceanographic connectivity. We further recommend that these analyses include integrated modeling of the combined effects of wind field modification and in situ structure friction and fish responses to hydrodynamic predictors relevant to their key habitats and life-cycle stages. Before impacts of OWFs can be tested, these models must demonstrate through, for example, uncertainty analyses, that they do in fact recreate realistic natural variability. The increased application of such integrated modeling could also be used to optimize data collection in relation to future OWF impact assessments. @

\section{REFERENCES}

Bergström, L., F. Sundqvist, and U. Bergström. 2013. Effects of an offshore wind farm on temporal and spatial patterns in the demersal fish community. Marine Ecology Progress Series 485:199-210, https://doi.org/10.3354/meps10344.

Bergström, L., L. Kautsky, T. Malm, R. Rosenberg M. Wahlberg, N.A. Capetillo, and D. Wilhelmsson. 2014. Effects of offshore wind farms on marine wildlife-A generalized impact assessment. Environmental Research Letters 9:034012, https://doi.org/10.1088/1748-9326/9/3/034012.

Boehlert, G., and A. Gill. 2010. Environmental and ecological effects of ocean renewable energy development: A current synthesis. Oceanography 23:68-81, https://doi.org/10.5670/ oceanog.2010.46.

Broström, G. 2008. On the influence of large wind farms on the upper ocean circulation. Journal of Marine Systems 74:585-591, https://doi.org/ 10.1016/j.jmarsys.2008.05.001.

Burchard, H., K. Bolding, T.P. Rippeth, A. Stips, J.H. Simpson, and J. Sündermann. 2002. Microstructure of turbulence in the northern North Sea: A comparative study of observations and model simulations. Journal of Sea Research 47:223-238, https://doi.org/10.1016/ s1385-1101(02)00126-0.

Burchard, H., K. Bolding, R. Feistel, U. Gräwe, K. Klingbeil, P. MacCready, V. Mohrholz, L. Umlauf, and E.M. van der Lee. 2018. The Knudsen theo- rem and the Total Exchange Flow analysis framework applied to the Baltic Sea. Progress in Oceanography 165:268-286, https://doi.org/ 10.1016/j.pocean.2018.04.004

Cañadillas, B., R. Foreman, V. Barth, S. Siedersleben, A. Lampert, A. Platis, B. Djath, J. Schulz-Stellenfleth, J. Bange, S. Emeis, and T. Neumann. 2020. Offshore wind farm wake recovery: Airborne measurements and its representation in engineering models. Wind Energy 23(5):1,249-1,265, https://doi.org/10.1002/we.2484.

Carpenter, J.R., L. Merckelbach, U. Callies, S. Clark, L. Gaslikova, and B. Baschek. 2016. Potential impacts of offshore wind farms on North Sea stratification. PLoS ONE 11(8):e0160830, https://doi.org/ 10.1371/journal.pone.0160830.

Cazenave, P.W., R. Torres, and J.I. Allen. 2016. Unstructured grid modelling of offshore wind farm impacts on seasonally stratified shelf seas. Progress in Oceanography 145:25-41, https://doi.org/10.1016/j.pocean.2016.04.004.

Chegini, F., P. Holtermann, O. Kerimoglu, M. Becker, M. Kreus, K. Klingbeil, U. Gräwe, C. Winter, and H. Burchard. 2020. Processes of stratification and destratification during an extreme river discharge event in the German Bight ROFI. Journal of Geophysical Research 125(8):e2019JC015987, https://doi.org/10.1029/2019jc015987.

Christensen, A., H. Mosegaard, and H. Jensen. 2009. Spatially resolved fish population analysis for designing MPAs: Influence on inside and neighbouring habitats. ICES Journal of Marine Science 66:56-63, https://doi.org/10.1093/ icesjms/fsn191.

Christiansen, M.B., and C.B. Hasager. 2005. Wake effects of large offshore wind farms identified from satellite SAR. Remote Sensing of Environment 98:251-268, https://doi.org/10.1016/ j.rse.2005.07.009.

COWI/VKI. 1992. Öresund impact assessment Sub-report nr. 2. The Öresundskonsortiet. Environmental impact assessment for the fixed link across the Öresund.

Degraer, S., D.A. Carey, J.W.P. Coolen, Z.L. Hutchison, F. Kerckhof, B. Rumes, and J. Vanaverbeke. 2020. Offshore wind farm artificial reefs affect ecosystem structure and functioning: A synthesis. Oceanography 33(4):48-57, https://doi.org/ 10.5670/oceanog.2020.405.

Djath, B., J. Schulz-Stellenfleth, and B. Cañadillas. 2018. Impact of atmospheric stability on X-band and C-band synthetic aperture radar imagery of offshore windpark wakes. Journal of Renewable and Sustainable Energy 10:043301, https://doi.org/ 10.1063/1.5020437.

Djath, B., and J. Schulz-Stellenfleth. 2019. Wind speed deficits downstream offshore wind parks - A new automised estimation technique based on satellite synthetic aperture radar data. Meteorologische Zeitschrift 28(6):499-515, https://doi.org/10.1127/ metz/2019/0992.

Fennel, W., T. Seifert, and B. Kayser. 1991. Rossby radii and phase speeds in the Baltic Sea. Continental Shelf Research 11:23-36, https://doi.org/10.1016/ 0278-4343(91)90032-2.

Floeter, J., J.E. van Beusekom, D. Auch, U. Callies, J. Carpenter, T. Dudeck, S. Eberle, A. Eckhardt, D. Gloe, K. Hänselmann, and others. 2017. Pelagic effects of offshore wind farm foundations in the stratified North Sea. Progress in Oceanography 156:154-173, https://doi.org/ 10.1016/j.pocean.2017.07.003.

Gill, A.B. 2005. Offshore renewable energy: Ecological implications of generating elec tricity in the coastal zone. Journal of Applied Ecology 42:605-615, https://doi.org/10.1111/ j.1365-2664.2005.01060.x.

Glarou, M., M. Zrust, and J.C. Svendsen. 2020. Using artificial-reef knowledge to enhance the ecological function of offshore wind turbine foundations: Implications for fish abun- dance and diversity. Journal of Marine Science and Engineering 8(5):332, https://doi.org/10.3390/ jmse8050332.

Grashorn, S., and E.V. Stanev. 2016. Kármán vortex and turbulent wake generation by wind park piles. Ocean Dynamics 66:1,543-1,557, https://doi.org/ 10.1007/s10236-016-0995-2.

Gray, C.A., and M.J. Kingsford. 2003. Variability in thermocline depth and strength, and relationships with vertical distributions of fish larvae and mesozooplankton in dynamic coastal waters. Marine Ecology Progress Series 247:211-224, https://doi.org/10.3354/meps247211.

Halouani, G., C. Villanueva, A. Raoux, J.C. Dauvin, F.B. Lasram, E. Foucher, F.L. Loc'h, G. Safi, E. Araignous, J.P. Robin, and N. Niquil. 2020. A spatial food web model to investigate potential spillover effects of a fishery closure in an offshore wind farm. Journal of Marine Systems 212:103434, https://doi.org/10.1016/j.jmarsys.2020.103434.

Halpern, B.S. 2003. The impact of marine reserves: Do reserves work and does reserve size matter? Ecological Applications 13(1):117-137, https://doi.org/10.1890/1051-0761(2003)013 [0117:tiomrd]2.0.co;2.

Hoff, A., J.L. Andersen, A. Christensen, and $\mathrm{H}$. Mosegaard. 2013. Modelling the economic consequences of marine protected areas using the BEMCOM model. Journal of Bioeconomics 15:305-323, https://doi.org/10.1007/ s10818-012-9135-3.

Kiørboe, T., and B. MacKenzie. 1995. Turbulenceenhanced prey encounter rates in larval fish: Effects of spatial scale, larval behaviour and size. Journal of Plankton Research 17:2,319-2,331, https://doi.org/10.1093/plankt/17.12.2319.

Kjelland, M.E., C.M. Woodley, T.M. Swannack, and D.L. Smith. 2015. A review of the potential effect of suspended sediment on fishes: Potential dredging-related physiological, behavioural, and transgenerational implications. Environment Systems and Decisions 35:334-350, https://doi.org/10.1007/ s10669-015-9557-2.

Krause, G., G. Budeus, D. Gerdes, K. Schaumann, and K. Hesse. 1986. Frontal systems in the German Bight and their physical and biological effects. Pp. 119-140 in Marine Interfaces Ecohydrodynamics, Elsevier Oceanography Series vol. 42, J.C.J. Nihoul, ed., https://doi.org/10.1016/ s0422-9894(08)71042-0.

Lampert, A., K. Bärfuss, A. Platis, S. Siedersleben, B. Djath, B. Cañadillas, R. Hunger, R. Hankers, M. Bitter, T. Feuerle, and others. 2020. In situ airborne measurements of atmospheric and sea surface parameters related to offshore wind parks in the German Bight. Earth System Science Data 12(2):935-946, https://doi.org/10.5194/ essd-12-935-2020.

Lass, H.U., V. Mohrholz, M. Knoll, and H. Prandke. 2008. Enhanced mixing downstream of a pile in an estuarine flow. Journal of Marine Systems 74:505-527, https://doi.org/10.1016/ j.jmarsys.2008.04.003.

Liao, J.C., and A. Cotel. 2013. Effects of turbulence on fish swimming in aquaculture. Pp. 109-127 in Swimming Physiology of Fish. A. Palstra and J. Planas, eds, Springer, Berlin, Heidelberg, https://doi.org/10.1007/978-3-642-31049-2_5.

Ludewig, E. 2015. On the Effect of Offshore Wind Farms on the Atmosphere and Ocean Dynamics. Hamburg Studies on Maritime Affairs, vol. 31, Springer, 162 pp., https://doi.org/ 10.1007/978-3-319-08641-5.

Maar, M., K. Bolding, J.K. Petersen, J.L. Hansen, and K. Timmermann. 2009. Local effects of blue mussels around turbine foundations in an ecosystem model of Nysted off-shore wind farm, Denmark. Journal of Sea Research 62:159-174, https://doi.org/10.1016/j.seares.2009.01.008.

Mellor, G. 2002. Oscillatory bottom boundary layers. Journal of Physical Oceanography 32:3,075-3,088, https://doi.org/10.1175/1520-0485(2002)032<3075: $\mathrm{OBBL}>2.0 . \mathrm{CO} ; 2$. 
Mineur, F., E. Cook, D. Minchin, K. Bohn, A. Macleod, and C. Maggs. 2012. Changing coasts: Marine aliens and artificial structures. Oceanography and Marine Biology: An Annual Review 50:189-234.

Mohrholz, V. 2018. Major Baltic inflow statistics - Revised. Frontiers in Marine Science 5:384, https://doi.org/10.3389/fmars.2018.00384.

Moore, P.G. 1991. Inorganic particulate suspensions in the sea and their effects on marine animals. Oceanography and Marine Biology: An Annual Review 15:335-363.

Nerge, P., and H. Lenhart. 2010. Wake effects in analyzing coastal and marine changes: Offshore wind farming as a case study. Pp. 68-73 in Zukunft Küste - Coastal Futures Synthesis Report. LOICZ Research \& Studies No. 36, GKSS Research Center, Geesthacht, $212 \mathrm{pp}$.

OSPAR. 2000. Quality Status Report 2000, Region II - Greater North Sea. OSPAR Commission for the Protection of the Marine Environment of the NorthEast Atlantic, London, $136 \mathrm{pp}$.

Pérez-Ruzafa, A., E. Martín, C. Marcos, J.M. Zamarro, B. Stobart, M. Harmelin-Vivien, S. Polti, S. Planes, J.A. García-Charton, and M. González-Wangüemert. 2008. Modelling spatial and temporal scales for spill-over and biomass exportation from MPAs and their potential for fisheries enhancement Journal for Nature Conservation 16:234-255, https://doi.org/10.1016/j.jnc.2008.09.003.

Reissmann, J.H., H. Burchard, R. Feistel, E. Hagen, H.U. Lass, V. Mohrholz, G. Nausch, L. Umlauf, and G. Wieczorek. 2009. Vertical mixing in the Baltic Sea and consequences for eutrophication: A review. Progress in Oceanography 82:47-80, https://doi.org/10.1016/j.pocean.2007.10.004.

Rennau, H., S. Schimmels, and H. Burchard. 2012. On the effect of structure-induced resistance and mixing on inflows into the Baltic Sea: A numerical model study. Coastal Engineering 60:53-68, https://doi.org/10.1016/j.coastaleng.2011.08.002.

Reubens, J.T., S. Degraer, and M. Vincx. 2011. Aggregation and feeding behaviour of pouting (Trisopterus luscus) at wind turbines in the Belgian part of the North Sea. Fisheries Research 108:223-227, https://doi.org/10.1016/ fishres.2010.11.025.

Reubens, J.T., F. Pasotti, S. Degraer, and M. Vincx. 2013. Residency, site fidelity and habitat use of Atlantic cod (Gadus morhua) at an offshore wind farm using acoustic telemetry. Marine Environmental Research 90:128-135, https://doi.org/10.1016/j.marenvres.2013.07.001.

Rivier, A., A.C. Bennis, G. Pinon, V. Magar, and M. Gross. 2016. Parameterization of wind turbine impacts on hydrodynamics and sediment transport. Ocean Dynamics 66:1,285-1,299, https://doi.org/10.1007/s10236-016-0983-6.

Scheffer, M., S. Carpenter, J.A. Foley, C. Folke, and B. Walker. 2001. Catastrophic shifts in ecosystems. Nature 413:591-596, https://doi.org/ 10.1038/35098000

Schröder, A., L. Gutow, T. Joschko, R. Krone, M. Gusky, M. Paster, and M. Potthoff. 2013. Benthosökologische Auswirkungen von Offshore-Windeneregieparks in der Nordsee (BeoFINO II). Abschlussbericht zum Teilprojekt B "Benthosökologische Auswirkungen von OffshoreWindenergie-parks in Nord- und Ostsee. Prozesse im Nahbereich der Piles". BMU Förderkennzeichen 0329974B (hdl:10013/epic.40661.d001).

Schultze, L.K.P., L.M. Merckelbach, J. Horstmann, S. Raasch, and J.R. Carpenter. 2020. Increased mixing and turbulence in the wake of offshore wind farm foundations. Journal of Geophysical Research 125(8): e2019JC015858, https://doi.org/ 10.1029/2019jc015858.

Siedersleben, S.K. 2019. Numerical Analysis of Offshore Wind Farm Wakes and Their Impact on the Marine Boundary Layer. PhD thesis, University of Köln, 108 pp., https://kups.ub.uni-koeln.de/ 10558/1/Siedersleben_2019_Dissertation.pdf.
Siedersleben, S.K., A. Platis, J.K. Lundquist, B. Djath, A. Lampert, K. Bärfuss, B. Cañadillas, J. SchulzStellenfleth, J. Bange, T. Neumann, and S. Emeis 2020. Turbulent kinetic energy over large offshore wind farms observed and simulated by the mesoscale model WRF (3.8.1). Geoscientific Model Development 13:249-268, https://doi.org/10.5194/ gmd-13-249-2020.

Simpson, J.H., and J.R. Hunter. 1974. Fronts in the Irish Sea. Nature 250:404-406, https://doi.org/ 10.1038/250404a0.

Simpson, J., P. Tett, M. Argote-Espinoza, A. Edwards, K. Jones, and G. Savidge. 1982. Mixing and phytoplankton growth around an island in a stratified sea. Continental Shelf Research 1:15-31, https://doi.org/10.1016/0278-4343(82)90030-9.

Simpson, J.H., J. Brown, J. Matthews, and G. Allen. 1990. Tidal straining, density currents, and stirring in the control of estuarine stratification. Estuaries 13:125, https://doi.org/10.2307/1351581.

Simpson, J.H., and A.J. Souza. 1995. Semidiurnal switching of stratification in the region of freshwater influence of the Rhine. Journal of Geophysical Research 100:7,037-7,044 https://doi.org/10.1029/95jc00067.

Simpson, J.H., H. Burchard, N.R. Fisher, and T.P. Rippeth. 2002. The semi-diurnal cycle of dissipation in a ROFI: Model-measurement comparisons. Continental Shelf Research 22:1,615-1,628, https://doi.org/10.1016/s0278-4343(02)00025-0.

Skov, H., S. Heinanen, C.B. Thaxter, A.E. Williams, S. Lohier, and A.N. Banks. 2016. Real-time species distribution models for conservation and management of natural resources in marine environments. Marine Ecology Progress Series 542:221-234, https://doi.org/10.3354/meps11572.

Slavik, K., C. Lemmen, W. Zhang, O. Kerimoglu, K. Klingbeil, and K.W. Wirtz. 2019. The large-scale impact of offshore wind farm structures on pelagic primary productivity in the southern North Sea. Hydrobiologia 845(1):35-53, https://doi.org/10.1007/ s10750-018-3653-5.

Smith, E.P., D.R. Orvos, and J. Cairns Jr. 1993. Impact assessment using the before-after-controlimpact (BACl) model: Concerns and comments. Canadian Journal of Fisheries and Aquatic Sciences 50(3):627-637, https://doi.org/10.1139/ f93-072.

Stenberg, C., M.V. Deurs, J. Støttrup, H. Mosegaard, T. Grome, G.E. Dinesen, A. Christensen, H. Jensen, M. Kaspersen, C.W. Berg, and others. 2011. Effect of the Horns Rev 1 Offshore Wind Farm on Fish Communities. Follow-up Seven Years after Construction. S.B. Leonhard, C. Stenberg, J. Støttrup, eds. DTU Aqua Report, No. 246-2011, 30 pp.

Stenberg, C., J. Støttrup, M. van Deurs, C. Berg G. Dinesen, H. Mosegaard, T. Grome, and S. Leonhard. 2015. Long-term effects of an offshore wind farm in the North Sea on fish communities. Marine Ecology Progress Series 528:257-265. https://doi.org/10.3354/meps11261.

Sumer, B., and J. Fredsøe. 1997. Hydrodynamics around Cylindrical Structures. World Scientific Singapore.

Tett, P. 1981. Modelling phytoplankton production at shelf-sea fronts. Philosophical Transactions of the Royal Society of London A 302:605-615, https://doi.org/10.1098/rsta.1981.0186.

Thomsen, F., A. Gill, M. Kosecka, M. Andersson,

M. Andre, S. Degraers, T. Folegot, J. Gabriel, A. Judd, T. Neumann, and others. 2015. MarVEN - Environmental Impacts of Noise, Vibrations and Electromagnetic Emissions from Marine Renewable Energy, Final Study Report. EUR 27738 EN, European Commission, Directorate General for Research and Innovation, Brussels, $72 \mathrm{pp}$.

Thomsen, F., L.O. Mortensen, and J.J. van Berkel. 2019. Agent-based modeling: Dynamic mapping of the movements of marine life. ECO - Environment Coastal and Offshore, http://digital.ecomagazine.com/publication frame.php?i=598395\&p=\&pn=\&ver=htm|5\&view= articleBrowser\&article_id=3416331.

van der Molen, J., H.C. Smith, P. Lepper, S. Limpenny, and J. Rees. 2014. Predicting the large-scale consequences of offshore wind turbine array development on a North Sea ecosystem. Continental Shelf Research 85:60-72, https://doi.org/10.1016/ j.csr.2014.05.018.

van Deurs, M., T.M. Grome, M. Kaspersen, H. Jensen, C. Stenberg, T.K. Sørensen, J. Støttrup, T. Warnar, and $\mathrm{H}$. Mosegaard. 2012. Short- and long-term effects of an offshore wind farm on three species of sandeel and their sand habitat. Marine Ecology Progress Series 458:169-180, https://doi.org/ 10.3354/meps09736.

van Dyke, M. 1982. An Album of Fluid Motion Parabolic Press, Stanford, CA, $176 \mathrm{pp}$

Wahlberg, M., and $\mathrm{H}$. Westerberg. 2005. Hearing in fish and their reactions to sounds from offshore wind farms. Marine Ecology Progress Series 288:295-309, https://doi.org/10.3354/ meps288295.

Wenger, A.S., E. Harvey, S. Wilson, C. Rawson, S.J. Newman, D. Clarke, B.J. Saunders, N. Browne, M.J. Travers, J.L. Mcilwain, and others. 2017. A critical analysis of the direct effects of dredging on fish. Fish and Fisheries 18(5):967-985, https://doi.org/ 10.1111/faf.12218.

Wilhelmsson, D., T. Malm, and M.C. Öhman. 2006 The influence of offshore wind power on demersal fish. ICES Journal of Marine Science 63:775-784, https://doi.org/10.1016/j.icesjms.2006.02.001.

\section{ACKNOWLEDCMENTS}

We are grateful for the assistance of Iris Tiong (DHI Water \& Environment Inc.) in creating several of the figures/tables.

\section{AUTHORS}

Joshua van Berkel (jvb@dhigroup.com) is Director of Environmental Projects (Canada and United States), DHI Water \& Environment Inc., Vancouver, BC, Canada. Hans Burchard is Professor, Leibniz Institute for Baltic Sea Research, Warnemünde, Germany. Asbjørn Christensen is Senior Scientist, DTU Aqua, Lyngby, Denmark. Lars O. Mortensen is Spatial Ecologist, Ole Svenstrup Petersen is Senior Engineer, and Frank Thomsen is Senior Marine Scientist, all at DHI A/S, Hørsholm, Denmark.

\section{ARTICLE CITATION}

van Berkel, J., H. Burchard, A. Christensen,

L.O. Mortensen, O. Svenstrup Petersen, and F. Thomsen. 2020. The effects of offshore wind farms on hydrodynamics and implications for fishes. Oceanography 33(4):108-117, https://doi.org/10.5670/ oceanog.2020.410.

\section{COPYRIGHT \& USAGE}

This is an open access article made available under the terms of the Creative Commons Attribution 4.0 International License (https://creativecommons.org/ licenses/by/4.0/), which permits use, sharing, adaptation, distribution, and reproduction in any medium or format as long as users cite the materials appropriately, provide a link to the Creative Commons license, and indicate the changes that were made to the original content. 